\title{
Importance of agricultural credit for rural development of Bangladesh: A descriptive approach
}

\author{
Md. Ariful Islam ${ }^{1}$ Md. Rayhan Islam², Mahmudul Hasan Siddiqui ${ }^{3}$, Luthful Karim ${ }^{4}$ \\ ${ }^{1}$ BASIC Bank Limited, Khulna, Bangladesh \\ ${ }^{2}$ Business Administration Discipline, Khulna University, Khulna-9208, Bangladesh \\ ${ }^{3}$ Unilever Bangladesh Limited, Gulshan-1, Dhaka-1212, Bangladesh \\ ${ }^{4}$ BASIC Bank Limited, Khulna, Bangladesh
}

\section{Email address:}

arifrussell@yahoo.com (M. A. Islam), rayhan_07@yahoo.com (Md. R. Islam),mhs.sadi@gmail.com (M. H. Siddiqui), shajiblks@gmail.com (L. Karim)

\section{To cite this article:}

Md. Ariful Islam, Md. Rayhan Islam, Mahmudul Hasan Siddiqui, Luthful Karim. Importance of Agricultural Credit for Rural Development of Bangladesh: A descriptive Approach. International Journal of Business and Economics Research.

Vol. 2, No. 1, 2014, pp. 68-83. doi: 10.11648/j.ijefm.20140201.18

\begin{abstract}
Adequate availability of credit on time is an important requirement for the rural people, particularly under conditions of scarcity of resources and uncertainty. Convenient and safes-saving facilities are perhaps even more important to smooth out the peaks and troughs in incomes and expenditures in the rural arena. Lack of savings facilities also force families to rely on inefficient, inconvenient and costly alternatives. Agricultural credit can be a solution for this perspective. In Bangladesh most of the agricultural credits are the small-scale loans for the poor entrepreneurs. It allows them to access in the lending institutions to borrow fund and start their own business for rural development. Several financial institutions developed several strategies, including provision of small loans to the rural poor without collateral. These loans are repayable in predetermined installments. Borrowers are organized into groups, which reduces the risk of being default. These credits also help disseminating valuable information about the borrowers and their living standards. In Bangladesh mainly nationalized Banks and specialized Banks are currently burdened with classified loans. But the collateral free financing offers a new opportunity to invest their funds with little risk. Previous experiences of financial institution show that small credits have proven feasible of lending to the poor for rural development. Therefore, we can say that if they can engage themselves efficiently, agricultural credit will accelerate the developmental activities in rural areas of Bangladesh.
\end{abstract}

Keywords: Agriculture, Credit, Development, Rural, Invest, Banks

\section{Introduction}

\subsection{Background of the Study}

In Bangladesh most of the agricultural credits are the small-scale loans for the poor entrepreneurs. It allows them to access in the lending institutions to borrow fund and start their own business. Several financial institutions developed several strategies, including provision of small loans to the rural poor without collateral. These loans are repayable in predetermined installments. Borrowers are organized into groups, which reduces the risk of being default. These credits also help disseminating valuable information about the borrowers and their living standards.

Adequate availability of credit on time is an important requirement for the investors, particularly under conditions of scarcity of resources and uncertainty. Convenient and safes-saving facilities are perhaps even more important to smooth out the peaks and troughs in incomes and expenditures. Lack of savings facilities also force families to rely on inefficient, inconvenient and costly alternatives. Agricultural credit is a solution for this perspective.

In Bangladesh mainly nationalized Banks and specialized Banks are currently burdened with classified loans. But the collateral free financing offers a new opportunity to invest their funds with little risk. Previous experiences of financial institution show that small credits have proven feasible of lending to the poor for rural development. Therefore, we can say that if they can engage themselves efficiently, agricultural credit will accelerate the 
developmental activities in rural areas of Bangladesh.

\subsection{Statement of the Problem}

For many years, Bangladeshi financial institutions have been fighting with the problem of large scale loan default. Their agricultural credit programs are performing better than their large scale projects. And their agricultural credit programs seem to be unsuccessful as compare to the case of Grameen bank. Therefore, it is necessary to examine why banks agricultural credit programs are not performing well. What could be done to make those financial institutions competitive in such agricultural credit programs?

\subsection{Objectives of the Study}

1. To explore the current scenario of agricultural credit in Bangladesh.

2. To identify the factors responsible for growth of agricultural credit in Bangladesh.

3. To test whether the selected financial institutions are successful enough in identifying hard core poor people of Bangladesh.

4. To show the impact of selected financial institutions in elimination of poverty.

5. To verify whether agricultural credit is effective to promote the economic standard in future.

\subsection{Methodology of the Study}

\subsubsection{Sample Design}

This study is intended to visualize involvement of financial institutions for rural development by agricultural credit operation in Bangladesh. Financial institutions of our country are comprised of banking financial institutions and non-banking financial institutions. Here banking financial institutions include Nationalized Commercial Banks (NCBs), Private Commercial Banks (PCB), Foreign Commercial Banks (FCBs) and Specialized Banks (SBs). Among them Bangladesh Krishi Bank (BKB) and Rajshahi Krishi Unnayon Bank (RAKUB) are providing agricultural credit specially. As Private Commercial banks and foreign banks do not participate in the agricultural credit programs to a great extent, they haven't been included in the sample unit. Micro financial institutions are also providing agricultural credit. This research also explores the possibilities whether Grameen Bank's agricultural credit model could be replicated by other financial institutions for rural development.

In sample designing, we have been chosen as sample units for the study considering the judgmental sampling method and the sample are as follows.

- Bangladesh Krishi Bank and

- Grameen Bank

\subsubsection{Source and Collection of Data}

Data are collected mainly from secondary sources such as

- Annual reports and publications of the concerned financial institutions,
- Government publication,

- Bangladesh Bank bulletin,

- World bank publication,

- Various journals,

- Published articles and

- Seminar paper.

\subsubsection{Data Processing and Analysis}

Data processing and analysis is done both manually and with the aid of electronic devices. Tabular, descriptive and suitable analytical tools are used in analyzing data. Both quantitative and qualitative analyses have been done on the findings. Following criteria are used for quantitative analysis:

1. Coverage recovery rate

2. Loan Disbursement

3. Share in the agricultural credit programs

For each of the above criteria, on a 1 to 3 scale was used to rank the banks' performance.

Qualitative analysis have been used on the following criteria:

- Dependence on international donor agencies

- The loan decision process

- Involvement in social development programs

For each of the above criteria, banks have been ranked (1 to 2 scale) on Qualitative judgment, such as high, moderate, and low; active and passive; dependent and independent.

Finally, overall findings have been drawn on by combining the positions of each bank based on both the quantitative and qualitative criteria.

\subsection{Limitations and Scopes}

This study is concerned with agricultural credit (small scale loan) activities only. Large-scale lending programs have been kept outside of the study. This study may suffer from unavailability of updated information as all financial institutions do not maintain sound records of their activities.

This study cannot avoid these limitations

- It takes account of only Bangladesh Krishi Bank and Grameen Bank.

- Time and financial statements of different organizations were the main constraint in the way of conducting the research.

- Though secondary data were available, but collection of detailed relevant data became almost impossible due to time constraint.

\section{Literature Review}

Ahmad, Farid (1980) in a study, "some aspects of agricultural credit in Bangladesh", observed that all development efforts for the economy have to fight against vicious cycle of poverty and large number of constraints. He said that agricultural credit facilities assumed a greater and growing importance in Bangladesh particularly in view of meeting the food deficit. It is observed that there are gaps between the policy procedure of institutional farm 
credit and their execution, for which proper distribution of credit cannot be ensured.

Gordon, Donald (1974) in a study, "Credit for small farms in developing countries", says that it is necessary to give particular attention to the small farmers of developing countries. Neither agriculture nor the small farmers have been rated very high in the operational thinking of most development theorists and practitioners until recently. Rather the small farmer has been seen as the main representative of the backwardness which developing countries were rejecting in their efforts to emulate the advanced industrialized countries.

Saha (1993) in a study, "BKB's linkage program in credit delivery", observed that BKB has taken the advantage of bringing the asset owned rural population into its credit net directly and indirectly the asset less rural people through the organizations associated with the "target group approach". The study shows that BKB's linkage program with the Grameen Bank (GB) project, Swanivar Bangladesh (SB) and CARE are the oldest. Profit sharing concept was then associated only with the BKB's credit delivery program with CARE and recently SB has accepted the profit sharing concept. Presently, Government Organizations (GOs), Foreign and Local NGOs, Private individuals etc. are associated with BKB's linkage program with profit sharing concept/interest spread sharing concept. Still now, only an insignificant portion of the total loan is linked with such type of financing and the major linkages are Agricultures Extension Project, Mymemmsingh (Danida Funded), Rural Women Employment Creation Project (ADB loan 1067), Small Holders Livestock Development Project (IFAD Funded), etc. The study concludes that under the new approach, technologically developed economic activities are to be resorted to financing and the task of identifying viable economic activities, skill training, group formation, social cohesiveness creating and financial discipline related tasks may be given to the NGOs and bank will be only in the financing task.

Karmakar K. G. (1999) in a study, "Rural credit and selfhelp group: Microfinance needs and concepts in India", observed that the provision of credit and generation of savings have long been recognized as an essential element in any rural development strategy. Credit plays a crucial role in the modernization of agriculture but its role in the fight against rural poverty has seldom been recognized. Financial institutions in developing countries, whether public or private have shunned in rural areas for various reasons such as opportunity cost and low financial credibility.

\section{Some Concepts \& Definitions}

\subsection{What is Agricultural Credit}

Agriculture includes crop production, fisheries, forestry, livestock, etc. Credit is the ability to participate in the production/development process. It is a device of that facilitates purchasing power. In Bangladesh mostly Agricultural Credit is the extension of small loans to the entrepreneurs through financial or non-financial institutions. Agricultural Credit has been used as a facilitator in many other community development activities, used as an entry point in a community organizing program or as an ingredient in a larger education/training exercise.

Somebody uses the term "micro credit" to mean agricultural credit, or rural credit, or cooperative credit, or consumer credit, credit from the savings and loan associations, or from credit unions, or from money lenders.

Usually in Bangladeshi agricultural credit programs extend small loans to very poor people for self-employment projects that generate income, allowing them to care for themselves and their families. Definitions differ, of course, from country to country.

\subsection{What is Rural Development}

Rural development means improvement of socioeconomic condition through comprehensive economic (agriculture and other related rural activities), social, cultural development including education, health, and human resources.

\subsection{Agriculture Credit Lending Models}

Financial institutions are using various Credit Lending Models throughout the world. Some of the models are listed below:

\subsection{Bank Guarantees}

As the name suggests, a bank guarantee is used to obtain a loan from financial institutions. This guarantee may be arranged externally (through a donor/donation, government agency etc.) or internally (using member savings). Loans obtained may be given directly to an individual, or they may be given to a self-formed group.

Bank Guarantee is a form of capital guarantee scheme. Guaranteed funds may be used for various purposes, including loan recovery and insurance claims. Several international and UN organizations have been creating international guarantee funds that financial institutions can subscribe to lend or start agricultural credit programs.

\subsection{Cooperatives}

A co-operative is an autonomous association of persons united voluntarily to meet their common economic, social, and cultural needs and aspirations through a jointly-owned and democratically-controlled enterprise. Some cooperatives include member-financing and savings activities in their mandate.

\subsection{Credit Unions}

A credit union is a unique member-driven, self-help financial institution. It is organized by and comprised of 
members of a particular group or organization, who agree to save their money together and to make loans to each other at reasonable rates of interest.

The members are people of some common bond: working for the same employer; belonging to the same church, labor union, social fraternity, etc.; or living/working in the same community. A credit union's membership is open to all who belong to the group, regardless of race, religion, color or creed.

A credit union is a democratic, not-for-profit financial cooperative. Each is owned and governed by its members, with members having a vote in the election of directors and committee representatives.

\subsection{Grameen}

The Grameen model emerged from the poor-focused grassroots institution, Grameen Bank, started by Prof. Mohammed Yunus in Bangladesh. It essentially adopts the following methodology:

A bank unit is set up with a Field Manager and a number of bank workers, covering an area of about 15 to 22 villages. The manager and workers start by visiting villages to familiarize themselves with the local milieu in which they will be operating and identify prospective clientele, as well as explain the purpose, functions, and mode of operation of the bank to the local population. Groups of five prospective borrowers are formed; in the first stage, only two of them are eligible for, and receive, a loan. The group is observed for a month to see if the members are conforming to rules of the bank. Only if the first two borrowers repay the principal plus interest over a period of fifty weeks do other members of the group become eligible themselves for a loan. Because of these restrictions, there is substantial group pressure to keep individual records clear. In this sense, collective responsibility of the group serves as collateral on the loan.

\subsection{Group}

The Group Model's basic philosophy lies in the fact that shortcomings and weaknesses at the individual level are overcome by the collective responsibility and security afforded by the formation of a group of such individuals.

The collective coming together of individual members is used for a number of purposes: educating and awareness building, collective bargaining power, peer pressure etc.

\subsection{Individual}

This is a straight forward credit lending model where micro loans are given directly to the borrower. It does not include the formation of groups, or generating peer pressures to ensure repayment. The individual model is, in many cases, a part of a larger 'credit plus' program, where other socio-economic services such as skill development, education, and other outreach services are provided.

\subsection{Intermediaries}

Intermediary model of credit lending position is a 'gobetween' organization between the lenders and borrowers. The intermediary plays a critical role of generating credit awareness and education among the borrowers (including, in some cases, starting savings programs. These activities are geared towards raising the 'credit worthiness' of the borrowers to a level sufficient enough to make them attractive to the lenders.

The links developed by the intermediaries could cover funding, program links, training and education, and research. Such activities can take place at various levels from international and national to regional, local and individual levels.

Intermediaries could be individual lenders, NGOs, microenterprise/microcredit programs, and commercial banks (for government financed programs). Lenders could be government agencies, commercial banks, international donors, etc.

\subsection{Village Banking}

Village banks are community-based credit and savings associations. They typically consist of 25 to 50 low-income individuals who are seeking to improve their lives through self-employment activities. Initial loan capital for the village bank may come from an external source, but the members themselves run the bank: they choose their members, elect their own officers, establish their own bylaws, distribute loans to individuals, and collect payments and savings. Their loans are backed, not by goods or property, but by moral collateral: the promise that the group stands behind each loan.

\subsection{Characteristics and Recent Successes of Agricultural Credit Programs}

Small-scale lending arrangements have long existed in many parts of the world, especially in the rural areas, and they still survive. All economies rely upon the financial intermediary function to transfer resources from savers to investors.

In many developing countries, overall interest rates are relatively high to begin with, so that rates charged by micro lending schemes are quite high when the risk premium is added. Many of these micro-institutions claim a high rate of repayment. This is attributable to the informal participatory structures, which create an atmosphere in which debtors respect their obligations. While this phenomenon is certainly true of the better-run institutions, it is not possible to verify whether this is a universal feature. There is little by way of "global" research in this area, even though the literature on agricultural credit has proliferated in recent years.

It should be noted that although a large number of studies undertaken so far on the impact of agricultural credit programs on household income show that participants of such programs usually have higher and more 
stable incomes than they did before they joined the programs, some practitioners still have reservations about the findings of those studies. Moreover, not many agricultural credit programs can afford to undertake impact assessments because they are generally expensive and timeconsuming. There are serious disagreements among experts on the validity of methodologies used in some of the published studies. In some cases, even the more rigorous studies have produced inconclusive results. Some studies show that there are limits to the use of credit as an instrument for poverty eradication, including difficulties in identifying the poor and targeting credit to reach the poorest of the poor. Added to this is the fact that many people, especially the poorest of the poor, are usually not in a position to undertake an economic activity, partly because they lack business skills and even the motivation for business.

\section{Agricultural Credit Programs- Grameen BANK}

\subsection{What is Grameen Bank}

In Bengali, the term 'Grameen' means 'rural'. Thus 'Grameen Bank' stands for 'rural bank'. It also explores the possibilities whether Grameen Bank micro credit model could be replicated by another banks. Specifically, the study identifies success factors in activities under taken by Grameen Bank and specialized bank's status in micro credit program as well.

\subsection{Grameen Bank in Different Angles}

In 1975, Professor Muhammad Yunus, chairman of the department of Economics, university of Chittagong, came across a village-woman who, used to make bamboo stools. Being financially in solvent, she borrowed the money from a local moneylender at exorbitant interest rate. Prof. Yunus came to know that she was making just five taka a day. He left the need for supplying credits to such poor women at reasonable interest rate so that they could take benefit from their hard work, which at that time was not possible due to the presence of middlemen and the money lenders, who appropriate the surplus. Yonus rightly identified the need for working or tools for the poor. Inquisitively, Yonus lent out a total of 14 to 43 villagers in the same situation at same situation at the rational interest rates. The recovery rate was overwhelming at $100 \%$.

Based on this experiment, Prof. Yunus requested some Bangladeshi banks to provide Collateral-free credits to the rural poor. Bankers rejected his idea: illiterate, landless peasants could never pay back the loans at one point, to convince the bank, Prof. Yunus guaranteed personally for the poor people; the loaned money was dully repaid. It strengthens Prof. Yunus's belief that poor people can utilize credit, and they are willing to pay back the loan in time.

In 1976, at the frequent request of Prof. Yunus,
Bangladesh Krishi Bank (BKB) stated the "Grameen bank project" in Jobra a village adjacent to the University of Chittagong. The Bank authorized Yunus to lay down the procedures recruit personnel and sanction loans. It became fully operational in1978. Finding the project successful, BKB undertook another "Grameen Bank Project" in Tangail in 1979. The project continued to run smoothly; the loan recovery rates remained $98 \%$ to $99 \%$.

After the abstaining success of "Grameen bank project" both in Jobra and Tangail, Prof. Yunus pursued the ministry of finance and Bangladesh bank to establish a new financial institution "Grameen bank", this would be totally different form the existing commercial and specialized Bank. At its inspection bankers strongly opposed to his idea of establishing a new bank on the grounds that the existing banks could provide collateral free loans; they ignored the need for establishing "Grameen Bank". Prof. Yunus however, continued his efforts to they government, and on October 21983 the "Grameen bank project" was transferred to the Grameen bank under the "Grameen bank ordnance1983". The ordnance was amended in 1986, which allowed $75 \%$ ownership by the poor while the rest remained with the Bangladesh government.

The GRAMEEN BANK's agricultural Credit model:

The Grameen model of agricultural Credit for rural people is based on that group collateral assumption can substitute physical collateral. the model has been shown in the following figure -

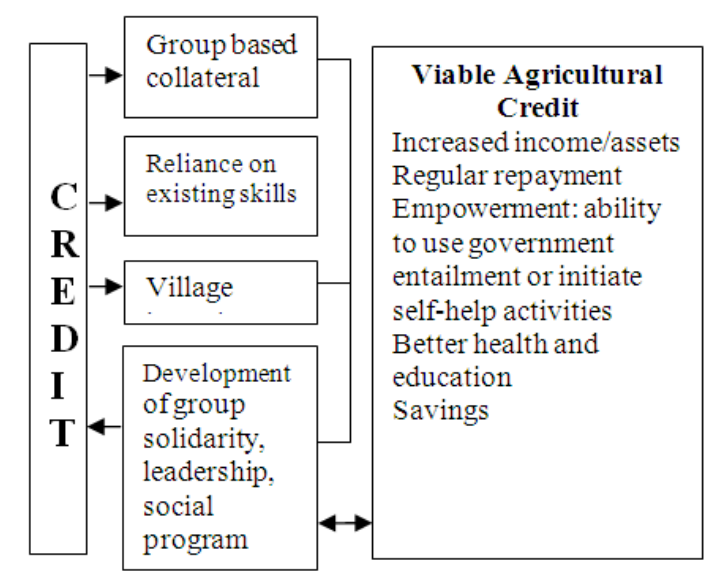

The Grameen bank micro- credit model assumes that the poor in rural areas already possess the skills, but not the small amount of capital, which is essential for undertaking a productive venture. Existing banks do not provide collateral credits; having no asset having no asset, the poor find no way to get loans from these banks. the Grameen bank model, through group collateral ensures development of income generating activities by the poor, empowering them especially women they become conscious about health, education and savings .under strong leadership the poor become united their improved economic status makes them creditworthy. Thus the collateral free credit to the poor generates self employment, which has significant importance in alleviating poverty. 


\subsubsection{The Grameen Approach to Poverty Alleviation}

To alleviate poverty Grameen bank follows the group approach to targeted credit. Grameen bank's poverty alleviation mechanism can be understood by observing its organization structure, mode of operation, and training and workshop.

\subsubsection{Organizational Structure}

Grameen bank's organization structure is highly decentralized. The bank's organizational structure may be described as circles within circles. Each is complete, but located within bigger circle. head office is the biggest circle, group being the smallest. Group belongs to the bigger circle of Centers, which belongs to the still bigger circle of Branches belong to the area office; Area office to the zonal office and zonal office to the head office.

Grameen bank is governed by a board of Governors. The board has 13 members of which 9 members are selected from the borrower -shareholders. Prof. Yunus, the Managing Director, is the Chief Executive of the bank. The bank considers branches, the lowest level units, profit center. Approximately 10 to 15 branches are supervised by an Area office, which is usually located in small town. With the help of a number of program officers, the Area manager finally approves loans and supervised loan utilization and recovery. The area offices are accountable to the zonal office located in the district head quarters. The zone managers handle accounts and manage funds they also monitor, evaluate and supervise the social development programs. The area managers attend management meetings once or twice in a month in zonal head office. The head office, located in Dhaka, maintain liaison with the Government and provides feedback to lower level offices. It has responsible for supervising the training of bank staff and for research and development.

Grameen bank gradually delegates decision-making power to the lower levels. The bank follows the consensual approach of formulating and changing policies through meeting with the Managing Director with the head s of various departments. The Managing Director meets with the zone managers twice a year to exchange experience and to discuss issue for further development of the bank. The branch managers are encourage to try their own ideas in the field and if successful, to pass them on to higher levels for testing and development and for possibility of replication in other areas. Borrowers' innovate ideas are also given due emphasis. To maintain close contact with borrowers and staff of the managing director spends much of his time in traveling across fields.

\subsubsection{Formation of Group/Center}

A person from a household owns less then 0.5 acre of cultivated land or with a value equivalent to less then 1.0 acre of medium quality land is eligible to receive a Grameen bank loan. Five eligible like -minded persons who satisfy the following conditions my form a group based on the following conditions may form a group based on the following criteria:
1. Similar economic back ground

2. Relative should not be in the same group

3. Enjoy mutual trust and confidence

4. Must be inhabitants of the same village

5. Only one member of a household may be in one group, if several people from a household want to join the bank they take membership in different groups in same center or in another center.

6. Female members form separate groups and centers

Each group elects a chairperson and a secretary hold the office for one year. They cannot be re-elected before all members have had the chance of assuming these positions. The group chairperson is responsible for maintaining discipline in the group. Members conduct their business with the bank through chairperson at weekly meeting. All members are obligated to attend weekly meeting and to be aware of the rules and regulation of the group.

Group form centers and weekly meeting are held at the centers. The group chairpersons elect a center chief and deputy center chief, who hold office for one year only. Center chief ensure attendance of the members at the weekly meeting, payment of loan installments and overall discipline and conduct the meeting and all bank business is conduct openly in the meeting in front of the members. It ensures transparency.

\subsection{The Loan Decision Process}

The loan decision process begins with the eligible member's identification of the small business s/he wants to finance and on estimate to capital require. This process has been shown following figure.

Usually, a proposal is discussed with in the group first and then in presence of bank assistance at weekly center meetings. The group center and bank assistance may suggest or encourage the members. The advice on appropriate amount of loan, but the selection of enterprises rest with the member. The bank assist help the members preparing the loan application form. After getting clearance from the group and the center, the proposal is passed on to the branch manager. Being convinced, the branch manager prepares her final loan proposal, which sent to the area office. If the application is complete and accurately prepared, the area officer authorizes the branch manager to disburse the loan. The entire process takes only a few weeks.

In the next phase all parties are involved in monitoring the loan utilization. It is group chairman; the center chief and the bank assistant certify that the member has used the loan for the intended purpose. The branch manager must endorse the certification.

The group and the center also informally monitor the loan utilization. Bank assistance attend weekly center meeting and report weekly to the branch manager on each center. The report is concerned with attendance and banking transaction, especially weekly payments. Failure to make weekly payments is considered as a bad sign in loan utilization. Frequent field visit by the program officers and 
area managers make it impossible for the loanee to misuse the Grameen Bank loan. Typically field officer spent 4.3 percent of their total time in the field visually monitoring loan utilization. Branch manager report weekly and monthly on branch activities, including the number of irregular borrowers and the number of loanees in difficulty. Area managers collect the weekly and monthly reports of the branch they supervise and transmit them to the zonal office. Distribution of roles in the general loan decision process has been shown in the table.

\subsubsection{Distribution of Roles in the General Loan Decision Process}

\begin{tabular}{llllll}
\hline & Identify & $\begin{array}{l}\text { Recommen } \\
\text { dation }\end{array}$ & $\begin{array}{l}\text { Autho } \\
\text { rize }\end{array}$ & $\begin{array}{l}\text { Disburs } \\
\text { e }\end{array}$ & $\begin{array}{l}\text { Impleme } \\
\mathrm{nt}\end{array}$ \\
\hline Member & $\mathrm{P}$ & & & $\mathrm{P}$ & $\mathrm{P}$ \\
Group & $\mathrm{S}$ & $\mathrm{P}$ & & $\mathrm{P}$ & $\mathrm{S}$ \\
Center & $\mathrm{S}$ & $\mathrm{P}$ & $\mathrm{P}$ & $\mathrm{S}$ \\
Bank & $\mathrm{S}$ & $\mathrm{P}$ & $\mathrm{P}$ & $\mathrm{S}$ \\
Worker & $\mathrm{P}$ & $\mathrm{P}$ & $\mathrm{P}$ & $\mathrm{S}$ \\
$\begin{array}{l}\text { Branch } \\
\text { Manager }\end{array}$ & $\mathrm{P}$ & & & $\mathrm{S}$ \\
$\begin{array}{l}\text { Program } \\
\text { Officer }\end{array}$ & & & & \\
$\begin{array}{l}\text { Area } \\
\text { manager }\end{array}$ & & $\mathrm{p}$ & & $\mathrm{S}$ \\
\hline
\end{tabular}

"p=primary role; $\mathrm{s}=$ secondary role"

Source: Grameen Bank; Performance Sustainability

In case of loan utilization problem, the responsibility for solving them is pushed down to the center and group levels for solution. In special cases, meeting of the center may be called to identify what action could be that are appropriate to a particular problem of repayment. Any decision taken must be one those sixteen decision" as stated in the Grameen bank construction.

\subsection{Grameen Bank's Programs}

Grameen Bank programs can be categorized into:

1. Economic development programs

2. Social development

\subsection{Economic Development Programs}

The economic development programs are meant to provide financial security to the poor as the often face unpredictable events.

\subsubsection{Group Fund}

The group fund account is accumulated account in which every group member deposits one taka each week as personal savings. The group members manage the group members manage the group on consensus basic. The member pay a group tax for enjoying the financial service coming to them through group. When a group member receives loan from bank, this obligatory deduction is made at the rate of $5 \%$ of the loan amount. The group tax is also deposited into the 'Group Fund Account'. Individual members do not have any claim in to the group tax. The fund protects the members from resorting to the money lender when they need small amount of money within short time. At the consent of other group members can borrow from the group fund for any purpose; invest or consumption.

\subsubsection{Emergency Fund}

It is mandatory that all the borrowers pay a fee of five per thousand for loans in excess of Tk. 1000 to the emergency fund, which is basically an insurance coverage in case of default, death, disability, and other accidents. Center members are responsible for identifying the Grameen Bank who is in need of urgently.

\subsubsection{Special Savings Fund}

The special saving contribution, which aims at developing joint enterprises, may vary from one to five taka per member per week. If a member of a center agrees to undertake a big project jointly they first demonstrate that they can save money together for that purpose. The bank will then supplement these funds with a loan. In general extends loan up to but not more than ten times the size of the members' savings. The center collectively repays the loan.

\subsubsection{Children's Welfare Fund}

The children's welfare fund requires each member to contribute Tk. 1 per week. However, this rule is applicable when a loanee takes his or her loan. The money is used for building or making arrangement for a modest school room, paying teachers and so on.

\subsection{Social Development Program}

The social development programs have three basic components a workshop program a center school program and availability of supplies and skill training.

\subsection{Workshop Program}

The zonal office have most important role in organizing workshops. Each zone offers a package of 17 workshops. These include workshop for woman exchange visit and follow up workshop. Besides area workshop and national workshop take place to disseminate new ideas and experiences among Grameen Bank stake holder.

\subsection{Supplies and Skill Training}

Under the supplies and skill training scheme the special training unit (SPU) of the training department supplies or assists the centers in obtaining of items such as cement slabs for pit latrines, tube -well equipment, water $\mathrm{p}$ [umps, power tillers, riffing, beehives, pigeon house, incubators, chicks, and ducklings, iodized salt, alum for water purification.

\subsection{Performance}

As of December 2011, performance of Grameen Bank stated below: 


\begin{tabular}{ll}
\hline Total number of members & $3,123,802$ \\
Total disbursement & $191,440.00$ million \\
Total outstanding & $16,017.40$ million \\
Total principal realization & $175,423.00$ million \\
Interest rate & $20 \%$ \\
\hline
\end{tabular}

Source: CDF MF statistics December 2011.

\section{Agricultural Credit Programs: Bangladesh Krishi Bank}

\subsection{Bangladesh Krishi Bank}

Bangladesh Krishi Bank (BKB) established in 1973 as a specialized government bank for agricultural development under the Bangladesh Krishi Bank Order (P O No. 27 of 1973). It is the successor to the former Agricultural Development Bank of Pakistan which was established in 1961 through merging the Agricultural Development Finance Corporation (established 1952) and the Agricultural Bank of Pakistan (established 1957) into one institution. Initially, the authorized capital of the bank was Tk 500 million and its paid up capital was Tk 370 million, subscribed fully by the government. Later, in view of the increased volume of banking activities and business, the authorized and paid up capital of the bank were raised to Tk 2 billion and Tk 1 billion respectively.

\subsection{Bangladesh Krishi Bank in Different Angles}

BKB provides credit facilities to individual and corporate bodies engaged in crop production, horticulture, forestry and fisheries. It also offers financial and technical assistance to agro-based and cottage industries. Its charter requires the bank to act on commercial considerations but with due regard to the development of agriculture, and agro-based and other related industries in rural and urban areas. Under the provisions of its charter, BKB is supposed to give preference to the credit needs of small farmers and other disadvantaged groups. BKB, therefore, has to fulfill both social and economic objectives. Being a scheduled bank, it also receives deposits in various accounts, performs foreign exchange business, and other banking functions.

The branches in the districts of Rajshahi division were separated from BKB to form a regional agricultural bank in March 1985. This was named as the Rajshahi Krishi Unnayan Bank. Other BKB branches have been put under divisional offices, which also have regional offices, each headed by either a deputy or an assistant general manager.

For effective administration of credit and supervision of branches, a regional auditing system has been introduced in the bank. Under the system, inspection teams from regional offices visit branches for verification of all aspects of their operations and make on-the-spot corrections as and when appropriate.

During the early years of its establishment, a major source of BKB's funds was the refinance from Bangladesh Bank. The bank gradually reduced its dependence on
Bangladesh Bank by increased mobilization of deposits in its accounts. Deposits rose at an annual rate of $90 \%$ during $1977-78$ to $1980-81$ as compared to an annual growth rate of $63 \%$ during 1972-73. The end of June deposits at the bank rose from Tk 1.761 billion in 1982 to $\mathrm{Tk} 31.431$ billion in 2000 . The advances made by the bank during $1977-78$ to $1980-81$ grew at an average rate of $93 \%$ as compared to $70 \%$ during $1971-72$ to $1977-78$. In 1983 , the BKB has advanced Tk 4.272 billion to 876,000 borrowers. Its total loans and advances rose to Tk 39.81 billion in 1998 and Tk 49.47 billion in 2000. Total overdue and classified loans of the bank in these two years were Tk 16.08 billion and Tk 25.79 billion or $40.40 \%$ and $52.14 \%$ respectably of total outstanding loans and advances. The low recovery rate and higher rate of non-performing overdue/classified loans worsened the performance of $\mathrm{BKB}$ and resulted in a reduction in the agricultural credit available for small and marginal farmers.

Bangladesh Krishi Bank made a total investment of Tk 1.453 billion in government securities, treasury bills, and debentures during 1998- 2003. The bank's total liquid assets on close of the calendar years 1998 and 2003 were valued at $\mathrm{Tk} 10.31$ billion and Tk 3.93 billion respectively and the total value of all assets of the bank on these dates was Tk 63.09 billion and Tk 69.81 billion. The assets that arose from the bank's off-balance sheet amounted to $\mathrm{Tk}$ 3.284 billion in 2003 .

The bank gives preference to financing crop production in a package. It offers short, medium, and long-term financing for production, processing, warehousing and marketing of agriculture and agro-based industrial products. Loan terms are determined by the purpose for which it is given, the gestation period, and income generating capacity. The bank provides short-term loans generally for seasonal agricultural production activities. The medium-term loans are sanctioned for acquisition of farm machinery, low lift pumps, hand pumps, agricultural implements, bullocks, carts, goats, dairy, poultry, and draft animals, transportation facilities for agricultural produces, and related development activities. Long-term loans are advanced for capital expenditures including purchase of tractors, power tillers and shallow tube wells, construction of ice plants, establishment of agro-based industries, extension of tea gardens or investment in horticulture, forestry and fisheries. Amortisation period for short-term loans is 18 months, for medium-term loans up to 5 years and for long-term loans over 5 years.

The major economic areas in which Krishi Bank lends (and the amount advanced up to 30 June 1999) are agriculture, hunting, forestry and fishing (Tk 25.785 billion), industries of all categories (7.483 billion), wholesale and retail trade, and hotels (1.262 billion), insurance, real estate and business services (1.617 billion), transport, storage and communication (613 million), special credit programs, including poverty alleviation (2.633 billion), and others (3.763 billion).

Apart from the above areas, BKB provides about Tk 14 
billion annually in financing numerous projects and special programs such as the Special Agricultural Credit Programs, and in helping contract growers of BADC, funding schemes of potato cultivation and preservation, tea plantation, and installation of hand pumps, shallow and deep tube wells, the Rural Finance Experiment Project, projects in dairy farming, poultry, fisheries, aquaculture and livestock, loans for production and marketing of tobacco, banana and cotton, the Betagi Community Forest Project, Swanirvar Bangladesh, and financing self-employment schemes of educated unemployed youths.

The total and net income of the bank on 30 June 2002 was Tk 3.65 billion and -Tk 1.89 billion respectively. The corresponding figures for 1998 were Tk 1.7 billion and -Tk 5.1 billion. The main reason for the bank's net losses during the last two decades was its excessive non-performing overdue/classified loans for which it had to maintain provisions. Other reasons included a decline in net interest income and commission and exchange incomes and increase in operating expenses.

The primary objective of $\mathrm{BKB}$ is to provide credit facilities to the farmers for the development of agriculture and entrepreneurs engaged in development of agro-based and cottage industries.

The Bank is guided in accordance with the policies and principles of the Government of the Peoples Republic of Bangladesh. BKB has an authorized capital of Tk. 2,000 Million (Taka Two thousand Million) only and paid up capital of Tk. 2,000 Million (Taka Two thousand Million) only which is fully paid by the government. The Bank started commercial functioning from 1977 to generate more loanable fund from the idle rural and urban savings and invest them for the betterment of our economy.

The Bank operates its function through 936 branches (except Rajshahi Division) of which 805 are rural and 131 are urban. It has 14 foreign exchange (Authorized Dealer) branches. In the field level the Bank has 8 divisional and 51 regional offices for close supervision of the branch activities. For smooth working it has also 56 field level audit offices at divisional and regional levels. In the Head Office the Bank has three divisions and 26 departments headed by General Managers and Deputy General Managers respectively. The Bank has 12998 employees as on 31 December 2011

\subsection{Credit Programs}

BKB finances the following 7 (seven) priority sectors, namely:

(1) Crop

(2) Fisheries

(3) Live Stock

(4) Agro-equipment and farm machineries

(5) Agro-processing industries

(6) Continuous Loan

(7) Poverty Alleviation and Agricultural Credit Programs

\subsubsection{Crop Loan}

Out of total annual allocation of Loan portfolio, $60 \%$ is earmarked for Crop financing. The Credit program covers all the seasonal crops produced in the country.

The loan is disbursed as per norms set by the Bangladesh Bank. The rate of interest for this sector is $8 \%$. The rate of interest may however, vary from time to time.

Both the landowner and sharecroppers are normally the target group for this loan. Marginal farmers are also eligible for the loan.

1. Crop loan is sanctioned on annual basis.

2. Credit passbook is issued to each borrower.

Food grains: Paddy, Wheat, Maize, Potato, Mustard etc.

Cash Crops: Tea, Jute, Sugarcane, Bettle leaf, Cotton etc.

Winter Crops: Beans, Vegetables, Carrot, Cauli- flower, Cabbage, Tomato etc.

Summer Crops: Cucumber, Ladies Finger, Korola etc.

\section{Horticulture \& Fruit Production}

1. Nursery development ( fruits, useful trees, flower, urbary culture, spices etc production \& marketing )

2. Banana, papaya, guava, pineapple, melon, water melon, bettle nut etc

3. Mushroom cultivation

4. Aromatic and fine rice

5. Lettuce, capsicum, broccoli, French bean \& other vegetables and promotion of export market

6. Spices (onion, garlic, ginger, turmeric etc)

7. Baby corn

8. Fruit production (mango, jackfruit, litchis, lemon, guava, pineapple, banana etc )

9. Floriculture (import substitutes \& exportable rajanigandha, ganda, rose, glandules, orchid, christmas tree, bonsai etc)

10. Import alternative fruit production (orange, grapes etc)

\section{Tea}

Tea is one of the major exportable items of the country. $\mathrm{BKB}$ is the exclusive financing institution providing credit to this sector. The Bank generally provides two types of loan - Tea production loan and Tea development loan.

1. Production Loan is for short-term basis. Rate of interest is $9 \%$.

2. Development loan is term loan. Rate of interest is $10 \%$.

3. Trading loan - Short term loan. Rate of interest is $12 \%$.

\section{Rubber plantation}

$\mathrm{BKB}$ is the premier financial institution for rubber plantation. This is one of the import substitute products.

\subsubsection{Fisheries Loan}

To accelerate fish production BKB provides loan for excavation and re-excavation of ponds, development of marshy lands, establishment of fish hatcheries and new fisheries projects. he Loans are given in the following sub sectors:

\section{White Fish}

1. Fish culture in existing pond/tank 
2. Fish culture by re-excavation of old/derelict tank/tank Fish culture by excavation of new tank/tank

\section{Shrimp culture (Marine, Brackish water and sweet water} Culture)

- $\quad$ Shrimp culture in traditional system (Bagda or Tiger Shrimp)

- $\quad$ Shrimp culture in scientific system

- $\quad$ Shrimp culture in semi-intensive method Prawn culture in sweet water(Galda)

This loan is given mainly in coastal areas for developed technology based shrimp culture.

\section{Fish \& Shrimp hatchery (fingerlings production):}

- $\quad$ Fingerlings production in sweet water

Shrimp fingerlings production fingerlings of commercially profitable technology)

\subsubsection{Live Stock Loan}

Live stock sector plays an important role in the development of agriculture. BKB provides loan for Bullock, Milch Cow, Goatery, Beef fattening and other draft animals. It is basically Medium Term Loan.

\section{Beef Fattening Program}

With a view to creating self employment for the poor and un-employed people of the country the bank has introduced a new program titled "Beef Fattening".

\section{Objectives of the program-}

- Create self-employment opportunity for poor and unemployed people.

- Meet national deficit of animal protein.

- Bring positive change in the attitude of the people through training.

- Ensure participation of bank officials in the program and increase their sense of duty and consciousness.

\section{Main Aspects-}

- $\quad$ Purely supervised credit.

- The bank officials giving guarantee are responsible for recovery of loan.

- $\quad$ Each borrower will get maximum Tk. 25,000/-for 5 calves ( each Tk. 5,000/-)

- Loan is collateral free.

- Repayable within one year.

\subsubsection{Agro Equipment \& Farm Machinery Loan}

With the Changing scenario the traditional agricultural system is being replaced by mechanized one. In order to meet up the changing demand of this sector, BKB offers credit facilities both for production and marketing of different agricultural equipment and farm machinery including irrigation equipment.

\subsubsection{Agro Processing Industries:}

As an agricultural country different types of crops and fruits are produced here. Moreover recently sectors like poultry, dairy, fisheries have flourished enormously. There is enough scope for export of these items through processing mechanism and value addition. The agrobased industries are - Poultry farm, Dairy farm, Food processing plant, Fish freezing/Processing Industries etc. Reputed local businessmen and prospective foreign investors are highly acceptable and encourage to the bank for establishment of any sorts of agro-processing industries in Bangladesh. Project under joint venture as well as direct foreign investors are specially taken care of.

\section{Poultry farm}

- Poultry broiler farm

- $\quad$ Poultry layer farm

- $\quad$ Poultry (broiler/layer) hatchery

- Poultry farm related/dependent project

\section{Dairy farm}

- Milk production

- Milk collection,

- Milk processing (ghee, butter, pasteurized milk etc production) and

- Marketing

\section{Food processing project}

- $\quad$ Fruit based food preparation, processing, preservation \& marketing

- Flour, bread \& biscuit vermicelli, noodles, chips., chanachur, corn flakes, potato flakes, French fry, popcorn, baby food, starch etc

- Juice, jam, jelly, tomato ketchup, sauce, pickle etc production \& marketing

- $\quad$ Spices processing

- $\quad$ Different types oil mill, dal mill etc

- Small processing industry at farm level

- Dehydrated fruit canning, packaging, preservation \& marketing

\section{Exportable items}

- $\quad$ Fish processing

1. Freezing plant Dehydration plant (for dry fish processing)

2. Salting and Dehydration of Jew fish.

- $\quad$ Leather process \& leather based products item

- Vegetables

\section{Import substitutes}

- $\quad$ Leather and Leather Goods

- Fish net/net thread production

- Garments accessories (garments allied industry like washing plant, packaging etc)

- $\quad$ Organic fertilizer, mixed fertilizer, urea super granules etc production \& marketing

- Insecticides production

- Bio-pesticide, neem based pesticide production

\subsubsection{Continuous Loan}

- The bank is providing continuous loan for different types of activities as cash credit/working capital loan on short term basis.

- Continuous loan is given for processing, preservation 
and marketing of agricultural products.

\subsubsection{Agricultural credit and other poverty alleviation Programrs/Projects}

Bangladesh Krishi Bank was established under BKB Order'1973 with the objective of strengthening rural economy by extending credit support to agricultural and agro-based sectors. In consideration of the importance of Micro-Credit and with the objective of generating employment as well as encouraging social development BKB has undertaken several Micro-Credit programs of its own and also in collaboration with local and foreign agencies. The programs have been designed to cover all segments of poor population whether skilled or unskilled such as small and marginal farmers, landless labourers, destitute women, disabled, unemployed youth and rural artisans etc. About 1388928 beneficiaries have been provided with Tk.9837.00 million since its inception.

Considering the needs of the target groups since late seventy's BKB has been implementing a series of MicroCredit programs out of which 09 programs have recently been completed and 23 programs are in operation at present. These diversified micro-credit programs are being implemented by BKB to achieve the following objectives:

- To create employment opportunities through income generating activities.

- To empower the rural women to establish their own rights.

- To improve the living standard of the rural people.

- To alleviate poverty of the poor people.

- To make easy access to institutional credit facilities and resources.

- $\quad$ To mobilize rural savings.

- To make optimum utilization of rural resources.

- To engage inactive human resources of the rural areas in productive/economic activities.

- To engage rural people in development process of the country.

- To eliminate exploitation by the money lenders.

\subsection{A Salient feature of BKB`s Present Agricultural Credit Programs under poverty alleviation is given below}

\subsubsection{Credit program for the landless and Marginal Farmers}

This program has been launched with BKB`s own fund in 1992-93 financial year through its all branches. Landless and marginal farmers get short term credit under this program. Persons/Peasants having not more than 1.50 acres of cultivable land and having annual income Tk 25000/- at the highest are eligible for getting credit under this program. After formation of groups and obtaining training the group members get credit without any collateral security. But they have to hypothecate the goods and assets created by the loan money. In lieu of collateral they have to take responsibility of guarantor for the loan of other persons of the group. The present Interest rate is $10 \%$. The loan is to be repaid on 52 equal weekly installments including interest. About 606102 beneficiaries have been provided with Tk. 4692.10 million since its inception.

\subsubsection{Beef fattening joint program}

This is a banks own financed program. Bank launched this program in 1994. The main objective of this program is to fill up the deficiency of animal protein in the country as well as creation of self employment for poor and unemployed people living in the villages. Under this program a person can get a loan amounting upto Tk.25000/- for 5 calves against guarantee of a bank official / local elite. The rate of interest is $10 \%$. The loan is to be repaid with interest in one installment within one year. About 47745 beneficiaries have been provided with Tk.1040.50 million since its inception.

\subsubsection{Swanirvar Credit Program}

Bank has been implementing swanirvar credit program since 1979 with a view to providing bank loan without collateral security, employment creation for the landless and marginal farmers, increasing their standard of living, creation of social and ethical values, eradication of illiteracy, providing creation of health and family planning services etc. The beneficiaries under the program are landless, rural poor \& destitute having maximum 0.40 acres of cultivable land and maximum annual income is Tk.20,000/-. 212 branches of 31 districts (regions) are involved in this program. The beneficiaries have to form groups (each Consisting 5 members) and a center(consisting 5 groups). BKB \& Swanirvar Bangladesh is operating this program jointly. The credit is collateral free but Group guarantee for each other is needed. Maximum loan amount is TK.10,000/- .Per beneficiary. It is Short term credit(to be recovered in 52 equal weekly installments within one year). Disbursement of loans to the beneficiaries is made duly recommended by Swanirvar staffs. Swanirvar Bangladesh is responsible for group formation, giving training to the beneficiaries and recovery of loan. Rate of Interest is 16\%. (6\% Service charge for Swarnivar, 10\% Interest for BKB). About 258016 beneficiaries have been provided with Tk.1197.30 million since its inception.

\subsubsection{Small Farmers \& landless Laborers Development Project (SFDP)}

This project is being implemented jointly by BARD \& BKB from 1995 through 21 branches under 6 Regions (districts) of Bangladesh Krishi Bank. The objectives of the project are to increase production, employment creation and increase income of the small landless farmers \& labourers through formation of small groups, generation of own capital and provision for capital support for undertaking various income generating activities. Under this project Tk. 19.80 million has been disbursed to 2710 beneficiaries on average per year and recovered Tk. 15.80 million per year. Cumulative recovery rate is $97 \%$. The beneficiaries under this program are small farmers having 
maximum 0.50 acres of cultivable land \& landless labourers having 0.51-1.50 acres of cultivable land. Selection of target family, group formation, supervision of group activities, supervision of loan utilization and all kinds of field works are done by BARD. Opening of group account, sanctioning and disbursement of loan \& maintaining savings account etc. are done by BKB. Bank provides credit from banks own source after formation 5-10 members group. The loan is collateral free, but assets and goods derived from credit are hypothecated. Lien of group savings \& group pressure replace the collateral. Loan is disbursed for any recognized items which is accepted by bank \& identified by members of group. Interest rate is $15 \%$ of which $10 \%$ for BKB, $5 \%$ for BARD. Chairman or secretary of the group recovers the loan. Loan is recovered in weekly/fortnightly/monthly installments within maximum 18 months. About 28236 beneficiaries have been provided with Tk.193.80 million since its inception.

\subsubsection{South Asia poverty Alleviation Program}

This program was launched on the basis of Dhaka conference of SAARC countries in 1993. This is a joint venture program with UNDP. But it is banks own financed program. UNDP organizes the beneficiaries, trains them and recommends the loan. The responsibility of credit realization lies with the managers of village organizations. This is an area based credit program. Only kishorganj (a district) sadar upazilla is the command area of this program The maximum credit limit is Tk. 25000/- per beneficiary. 25 beneficiaries form a group. Rate of interest is $15 \%$ (BKB $10 \%$ and the manager of village organization $5 \%$ ). The loan is collateral free and is recovered in weekly installments within one year. About 36179 beneficiaries have been provided with Tk.325.50 million since its inception.

\subsubsection{United Nations capital Development Fund(UNCDF)}

This program started in 1983 with the objective of financing rural \& cottage industries. Now it is running on revolving fund. This is a joint venture program with $\mathrm{BKB}$, BSCIC \& UNCDF. UNCDF provides one third of fund while BKB provides two thirds. BSCIC selects borrower and provides extension services. The program covers 29 districts. BKB provides credit from joint fund and maintains account. Rate of interest is $10 \%-14 \%$. This is a collateral free credit. Raw materials, finished goods and capital asset created out of credit are kept as hypothecation against credit provided to the beneficiaries. About 21439 beneficiaries have been provided with Tk.110.50 million since its inception.

\subsubsection{Rural Women employment creation Project $A D B$ loan no $1067 \mathrm{BAN}(\mathrm{SF})$}

This is a joint project started in 1993 for experimenting with the idea of co-participation of government Organizations (GOs) and Non-Government Organizations (NGOs) aiming at employment creation for poor women in the rural areas. Department of women Affairs(DWA), 19
NGO's in 12 thanas (upa-zilla)and BKB jointly implementing the project. NGOs organizes individuals into groups, train them under the supervision of DWA and recommends for credit funded by ADB. This is also a collateral free credit. Interest rate is $12 \%$. About 72266 beneficiaries have been provided with Tk.1424.60 million since its inception.

\subsubsection{BKB-NGO Micro Credit Program}

This program is a replication of Rural Women Employment Creation Project(RWECP).NGOs organizes individuals into groups, provides them training and recommends for credit. BKB provides credit from its own fund. This is also a collateral free credit. Interest rate is $12.5 \%$. About 18319 beneficiaries have been provided with Tk. 143.10 million since its inception.

\subsubsection{Credit Under National Poverty Alleviation Program through Goat Rearing}

This program have been introduced in 2002 aiming to eradicate poverty through goat rearing. Directorate of livestock provides with extension service while BKB provides credit from its own fund for a period of 4 years term. This is a collateral free credit provided from all branches of BKB. Interest rate is $10 \%$. About 12671 beneficiaries have been provided with Tk. 115.70 million since its inception.

\subsubsection{Milking cow credit program for women}

The program launched in the year 1997. The main objectives of the program were proper utilization of the unemployed women increasing milk production and helping the up-lift of the condition of the women folk. Under this program one village of a branch area is selected. One women from each family of the selected village is eligible to get this credit facility. An applicant gets maximum Tk. 10,000/- to purchase a calf. Interest rate is $8 \%$. The loan is realized within one year in weekly installments. This is a collateral free supervised credit. An officer or field worker of the branch is engaged in supervising the credit under the direct control of the branch manager. Livestock officers help the beneficiaries in treatment and rearing the cow.

\subsubsection{Special Micro Credit Program for the Disabled}

This program have been introduced in 2002 aiming to income generation \& development of socio-economic condition through employment creation for the disabled persons. Department of Social Welfare and Disabled Foundation provides extension services. This is a collateral free credit provided from all branches of the bank. Interest rate is $10 \%$. About 75 beneficiaries have been provided with Tk. 1.0 million since its inception.

\subsubsection{Micro Enterprise Development for the Monipuri (MEDM) Credit Program}

This program have been introduced in 2003 aiming to provide working capital to handloom industry operated by the Monipuri women living in the greater Sylhet areas. 
Bank officials organizes the Monipuri women having handloom and training/education/experience of operation. Eligible women are organized into 5 member groups. This is also a collateral free credit provided from the bank`s own fund. Interest rate is $10 \%$. About 105 beneficiaries have been provided with Tk.2.3 million since its inception.

\subsubsection{Special Credit Program for the Rakhain's under the district of Cox`s Bazar}

This program have been launched in 2003 aiming to provide working capital credit for producing handloom and cottage Industrial products and marketing. The loan is disbursed to the Rakhain community living in the district of Cox`s Bazar. Bank officials organizes Rakhains into 5 member groups. This is a collateral free credit program from banks own fund. Interest rate is $10 \%$. About 385 beneficiaries have been provided with Tk. 8.1 million since its inception.

\subsubsection{Tree Plantation Programs: In 2002 and 2003 BKB has launched 8 Tree Plantation Programs-viz}

All types of tree nursery including herbal,

- Horticulture Development,

- $\quad$ Fruit and forest tree plantation,

- Bamboo production,

- Herbal gardening,

- Coconut gardening,

- Patipata (a plant used in making mat) production,

- Cane production.

These programs is being introduced in all branches of the bank to grow more and more trees aiming to eradication of poverty, proper use of fallen land, increase of tree production facilitating herbal treatment and development of environment. Credit under these programs is collateral free upto Tk. 25,000/-. Interest rate is $8 \%$. About 8400 beneficiaries have been provided with $\mathrm{Tk} 153.10$ million since its inception.

\subsubsection{Establishment of Breeding Farm of Black Bengal Goat Program}

This program has been taken to ensure supply of kids of Black Bengal Goats in order to support the national program of poverty alleviation through goat rearing. Under this program a farm comprising 50 she goats is considered as a small farm and a farm comprising 51-200 she goats is considered as a big farm. The loan is medium term. Credit limit is Tk. 30,000/- for a small farm consisting of 10 she goats( with a he- goat). This credit limit is calculated for making up goat-shed, purchasing of she-goats \& he-goat and initial feed cost. This limit is proportionate for a small farm having unto 50 number of she-goats. For a medium farm credit limit is to be calculated deducting the cost of goat shed. This cost is borne by the entrepreneur.

\subsubsection{Community Based Resource Management Project}

This project started in 2003-04 fiscal year. It is a joint venture project of BKB, IFAD and Dept. of LGRD of GOB. The project is to be implemented in all of the 10 upa-zillas of sunamgonj(a district) at 3 phases within 11 years. The project has five components such as: (1) Infra -structure Development, (ii) Development of Fisheries, (iii) Crop and livestock Development, (iv) Grass Roots Institutional Development and (v) Small Credit Bangladesh Krishi Bank deals with "small credit" component of the project. LGRD organizes the target people into 30 member groups. Bank Provides short and medium term loan. M Maximum loan limit is Tk. 14,000/- to each member as short term and Tk. 27,000/- to each member as Medium term. The loan under this project is collateral free. Rate of interest is $15 \%$.

\section{Analysis and Findings}

This chapter discusses the analysis and findings on the two sample banks and their agricultural credit programs discussed in previous chapters.

\subsection{Analysis}

For each case, the analysis is presented. Finally, an overall finding is shown of the entire research work. This analysis is based on the financial year 2010 and 2011.

\subsubsection{Contribution to Agricultural-Credit}

Grameen Bank provides $30.40 \%$ and agricultural banks(BKB \& RAKUB) provide $1.8 \%$ of the entire microcredit loans to the poor in Bangladesh. Grameen Bank aim at helping the poor so as to facilitate improving their economic and social conditions. For the poor Grameen Bank's involvement in poverty alleviating activities is not the prime concern.

Table 1. Share of agricultural credit activities (as of 2011)

\begin{tabular}{ll}
\hline Sources & Share in percentage (\%) \\
\hline Grameen Bank & 30.4 \\
Agricultural Banks (BKB \& RAKUB) & 1.8 \\
\hline
\end{tabular}

Source: CDF - MF Statistics, 2003

\subsubsection{Recovery Performance}

Grameen Bank (99.69) recovery rate has been found the most satisfactory in agricultural credit programs, followed by BKB's $(85 \%)$. It is possible for the bank to closely monitor and supervise its projects, which result in excellent recovery performance. Grameen bank with its dedicated work force and loyal members, being driven by charismatic leadership, uses the innovative model of credit delivery to the poor successfully in agricultural credit programs. This may be the result of joint collaboration between various donor agencies whose terms and conditions of funding are very strict and effective.

Table 2. Recovery performance (as of 2011)

\begin{tabular}{ll}
\hline Items & Recovery rate (\%) \\
\hline Bangladesh Krishi Bank & $85 \%$ \\
Grameen & 99.69 \\
\hline
\end{tabular}


Source: Bangladesh Economic Review, Ministry of Finance, 2011

\subsubsection{Coverage of Agricultural Credit Programs}

Number of employees, beneficiaries, branches and number of beneficiaries per employee are higher in Grameen Bank compare to Bangladesh Krishi Bank. It indicates that there acceptance is increasing rapidly.

Table 3. Coverage of agricultural-credit programs (as of December 2011)

\begin{tabular}{llllll}
\hline $\begin{array}{l}\text { Name of the } \\
\text { bank }\end{array}$ & $\begin{array}{l}\text { No. of } \\
\text { employe } \\
\text { es }\end{array}$ & $\begin{array}{l}\text { No. of } \\
\text { branch } \\
\text { es }\end{array}$ & $\begin{array}{l}\text { No. of } \\
\text { benefic } \\
\text { iaries }\end{array}$ & $\begin{array}{l}\text { No. of } \\
\text { beneficiaries } \\
\text { per employee }\end{array}$ & $\begin{array}{l}\text { Ra } \\
\text { nk }\end{array}$ \\
\hline $\begin{array}{l}\text { Grameen } \\
\text { Bank }\end{array}$ & 12000 & 1,195 & $\begin{array}{l}3,123,8 \\
02\end{array}$ & 260 & 1 \\
Bangladesh & 10,998 & 936 & $\begin{array}{l}1,347,4 \\
79\end{array}$ & 123 & 2 \\
Krishi bank & & & 79 & \\
\hline
\end{tabular}

Source: Annual reports of GB and BKB, 2003

\subsubsection{Dependence on Donor Agencies}

Grameen bank and Bangladesh Krishi Bank depend on donor agencies for sources of funds. Grameen Bank has the trained workforce and logistic supports enabling it to monitor and supervise agricultural credit projects very closely. However, due to the lack of adequate sources of funds, bank has to rely on foreign aids. Grameen Bank used to get grants from international donor agencies. Now, the bank has become self sufficient in the context that it can borrow from those agencies, rather than accepting grants. These 2 banks are dependent on donor agencies for supervising their agricultural credit programs. Lack of adequate trained work force and logistic support result in high dependence on donor agencies.

Table 4. Dependence on donor agencies

\begin{tabular}{lll}
\hline Name of The bank & State of dependence & Rank \\
\hline Bangladesh Krishi Bank & Moderate dependence & 2 \\
Grameen Bank & Low dependence & 1 \\
\hline
\end{tabular}

Source: Activities of Banks \& Financial Institutions, Ministry of Finance, Bangladesh.

\subsubsection{Loan Recovery Process}

With regard to loan decision process, Grameen bank highly delegates authority to its field staff to fix terms and conditions of the loan agreement. As a result, the bank can approve the loan within a very short time (2-4 weeks). Bangladesh Krishi bank does not allow their field official to have significant authority over loan decisions. Besides, Grameen Bank welcomes suggestions from it's members (borrowers) so as to improve the viability of any rejects. These features are absent in Bangladesh Krishi bank loan decision process.

Grameen Bank believes in participatory management, decisions in the bank are made on a consensus basis. It values the members' ideas about potential projects. In making decisions, the bank follows the Bottom Up approach, where information flows from the lower level to the top management. Unlike, the Bangladesh Krishi bank
Grameen Bank management style are free from bureaucracy. All these factors contribute to the banks prompt action, which are not found in Bangladesh Krishi bank.

\subsubsection{Involvement in Social Development Programs}

Grameen Bank is highly involved in social development programs. These include formal education and training, group fund scheme, and emergency fund scheme, and emergency fund scheme. Bangladesh Krishi bank, on the other hand, has the least involvement in social development programs. Bangladesh Krishi bank is involved in such activities to some extent. Social development programs promote awareness about living standards, human right, and dignity. Grameen Bank's approach to teach the woman about family planning, promoting the habit of group saving (which can be treated as insurance policy), and emergency funds highly contribute to uplift men of living slandered among the poor. The Bangladesh Krishi bank does not value involvement in social development programs in that that much.

\subsection{Findings of the Study}

This study aimed at understanding the historical development of Grameen Bank and it's agricultural credit model. It Evaluates agricultural credit programs of another financial institute, identifying the success factors of Grameen Bank and explore the possibilities of replicating Grameen Bank's agricultural credit model.

Grameen Bank's agricultural credit model is in the philosophy that group collateral can substitute physical collateral. The bank provides fund to the poor who do not possess physical assets, can also get credit from through group collateral. In the Grameen Bank's group approach of agricultural credit delivery, the poor were found loyal to loan repayments. Thus, Grameen Bank, which was established in 1983, has undermined the concept of traditional banking where credit couldn't be delivered without physical collateral.

Bangladesh Krishi bank has been found not to be performing very well in agricultural credit activities. Legal framework as well as lack of top management vision with unskilled and de-motivated human resources and largescale bureaucracy contributes to this performance of the banks.

Factors that contribute to Grameen Bank's success include

- Close relationships between the bank and borrowers;

- Understanding among themselves;

- $\quad$ Peer pressure and support;

- Targeting the rural women who are more practical than men;

- $\quad$ Reaching the poorest of the poor;

- Motivated work force with adequate authority;

- Transparency;

- Ownership mode; and

- Visionary leadership by prof. Yunus. 
Thus replication of Grameen Bank's agricultural credit model by other financial institutes require much modification so as to accommodate the operating environment of the agricultural credit programs.

\section{Conclusion and Recommendations}

\subsection{Conclusion}

Grameen bank's agricultural credit model has been established one of the basic human rights; access to credit. The overwhelming success of the bank has brought a positive change in the loan default attitude among the borrowers and the society. This is suggested that other financial institutions should under take such agricultural credit programs, after some adjustments. Hopefully this will result in better recovery performances in the long run. Thus financial institutions would be able to play massive role in rural development through enhancing the scope of increased income-generating activities among the poor.

Financial institutions can use their manpower for reaching to the rural poor people and thus it can minimize their transaction cost and eliminate supervision cost. The cost will be minimized if the loan amount is large and per unit transaction cost will be coming down.

So we can figure the conclusion that though there are some existing problems, there have lot of possibilities for the financial institution to involve in agriculture credit for rural development.

\subsection{Scope for Future Research}

Grameen bank has revolutionized the traditional banking concept through its group lending approach to agricultural credit programs. It is apparent that the same model will not work in some other financial institutions. It would be of utmost importance to carry out future research to explain why some programs succeed and others fail, given the same environment. Again, many agricultural credit programs provide non-credit services to their borrowers. It is widely believed that such non-credit services increase productivity and income of the poor, but it is yet to be quantified. Future research may focus on how non-credit inputs benefit the borrowers.

\subsection{Recommendation}

Grameen Bank has been successful in pursuing its main objective, serving the poor with competitive price. The bank should maintain the status quo. This will enable the existing resources to mobilize among the various units within the bank. By this time, bank could also develop a stringent checkpoint to ensure accountability for it's staff and the members. Later where the bank builds enough resources it could expand. it would be a pragmatic idea to include more people, who fall within the target group under Grameen Bank's umbrella.

Financial institutions of Bangladesh, on the other hand, need to re-orient their activities to agricultural credit activities. Following are some recommendation which they could follow for this purpose:

1. Financial institutions should not vow to replicate the Grameen Banks agricultural credit model as it is. Due to differences in various organizations and environmental factors. It is apparent that merely replicating such a model could simply not work for the others.

2. Financial institutions should recruit young, energetic graduates with excellent academic background. They then should be trained by the bank's training institution as per recruitment for serving the rural poor. However, they should increase their recruitment and training budgets for this purpose.

3. It is suggest that agricultural credit activities should be entirely controlled by special units of the financial institutions. Field workers should have enough authority and responsibility to execute all agricultural credit function. This will result in speedy decision making.

4. Financial institutions should ask the branch manager to set up their own recovery targets each year. They must investigate any discrepancy between the targets and actual result. However, they should link performance to pay, e.g. bonus for achieving the targets and vice-versa.

Finally, the Bangladesh Government should modify the legal framework and provide all support to the financial institutions in undertaking agricultural credit programs aimed at rural development.

It is very difficult for the Bangladeshi Financial institutions to implement all the suggestions mentioned above. Unavailability of resource and bureaucracy along with strong opposition from trade unions may undermine the possibilities of adopting the recommendations. In addition, these recommendations are only valid for developing countries. For the purpose of rural development, financial institutions in the other region of the world may not find them useful because of difference in various factors such as cultural, legal framework and organizational structure etc.

\section{References}

[1] Shehabuddin, Rahnuma. The Impact of Grameen Bank in Bangladesh. Dhaka: Grameen Bank, 1991.

[2] Wahid, Abu N M. The Grameen Bank:Poverty Relief in Bangladesh. USA: Westview Press, 1993.

[3] Khandker, Shahidur R. Fighting Poverty with Microcredit: Experience in Bangladesh. The University Press Limited:Dhaka, 1998.

[4] Alam, Nurul, and Sayeeda Bilquis Jahan. "Default Culture in Banking Sector of Bangladesh.” Bank Parikrama, Vol. XXIV, No. 1, March, 1999. 
[5] Kothari, C. R. Research Methodology, Methods and Techniques, 2nd Edition, Wishwa Prakashan, New Delhi, India. 2001

[6] Lesikar, Raymond V. and John D. Pettit. Jr., Business Communication Theory and Application, 6th Edition, Richard D. Irwin Inc., USA. 1994.

[7] Hossain, Mahabub. "Institutional Credit for Rural Development Overview of Bangladesh." Journal of Agriculture Economics, Vol. 8, No. 1 (June 1985).

[8] Hashemi, Syed M, Sidney Schuler and AnnRiley. "Rural Credit Programs and Women's Empowerment in Bangladesh". World Development, April 1996.

[9] Choudhuri, A.H.M. Nurul, Islam, et al. "Restructuring Rural Banking in Bangladesh", Bank Parikrama, March-June, 1994.
[10] Bangladesh Bank. Annual Report. Dhaka, Bangladesh. 2000-2004 \& 2010-2011

[11] Bangladesh Krishi Bank, Annual Report. Dhaka, Bangladesh. 1998-2003

[12] Grameen Bank, Annual Report. Dhaka, Bangladesh. 19982003

[13] Credit and Development Forum, Microfinance Statistics. Volume 16, December 2011.

[14] Ministry of Finance, Activities of Banks and Financial Institutions. Dhaka, Bangladesh 2010-2011.

[15] Ministry of Finance, Bangladesh Economic Review. Dhaka, Bangladesh. 2004. 